\title{
EDITORIAL
}

\section{Myths in wine and medicine}

(c) The Author(s), under exclusive licence to Springer Nature Limited 2021

Bone Marrow Transplantation (2022) 57:333-335; https://doi.org/ 10.1038/s41409-021-01530-4

'Wine enters through the mouth, Love, the eyes. I raise the glass to my mouth'.

William Butler Yeats (1865-1939). Irish poet and dramatist. Fig. 1

Myths persist because of psychological and sociological factors. Napoleon Bonaparte, no matter what you may think of him, was a military genius, an able administrator, a politician and a hubristic human being. The composer, Ludwig van Beethoven Fig. 2, was a great fan of Napoleon and even wrote a famous concerto, piano concerto No 5, commonly known as 'The Emperor Concerto'. Apparently, the original concerto was not dedicated to Napoleon but to Archduke Rudolf but the legend persists. Beethoven lost his enchantment with Napoleon as he became more acquisitive and especially when Napoleon crowned himself Emperor of France in the cathedral of Notre Dame in 1804. Whether Napoleon actually took the crown from the Pope and placed it on his own head, is unclear, but the legend still exists.

In the world of haematology many beliefs exist, although they may not be true. Although 'cults' are commonly believed to be related to religious behaviour, Gale and Lazarus [1] point out that haemopoietic cell transplanters may come under the same heading. A common misbelief is that aspirin (acetylsalicylic acid, ASA) reduces the platelet count and is a "blood thinner'. Aspirin, as we know, is an irreversible inhibitor of the enzyme cyclooxygenase (COX-1) and modifies the action of COX-2 thus inhibiting platelet function but does not affect the blood clotting system directly. It may seem a moot point but aspirin in not an anticoagulant. Myths about blood transfusion (you can get an infection from donating blood) abound as do myths surrounding the area of sexually transmitted infections (STIs) and in spite of constant rebuttal these myths persist. For example you can't get an STI from a toilet seat!

The battle to preserve the difference between signs and symptoms [2] continues but seems to be loosing ground. It is particularly annoying to hear people talking or writing about animals having symptoms and unfortunately some renowned wine writers fall into the same trap when writing about vines and grapes.

The most widely known stories about wine are the myths surrounding Dionysus/Bacchus, the god of wine. There are many myths but it seems that Ampelos, Dionysus' lover, was killed in a hunting accident. A vine grew from his body and Dionysus made wine from it! Ampelography is the term given today to the study of varieties of vines.

Leaving myths to the believers, the war of words/description in wine continues, unabated, in Italy. I agree with Jason Horowitz

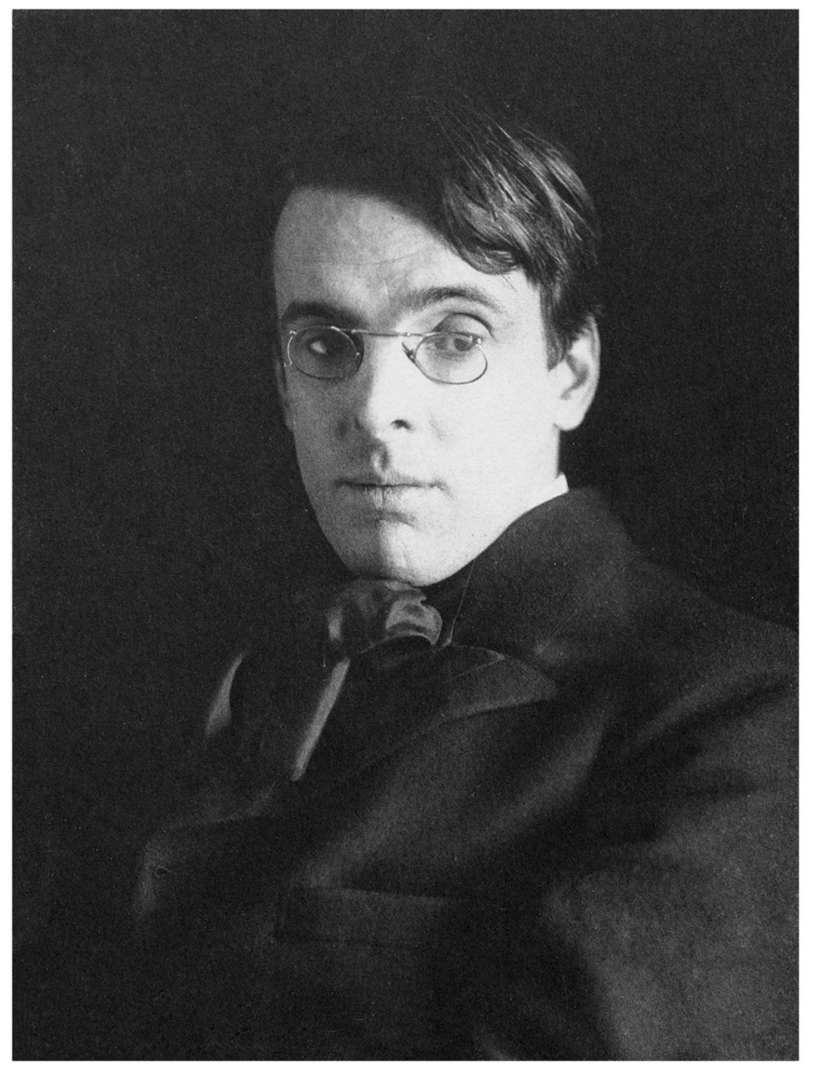

Fig. 1 W B Yeats. William Butler Yeats. Irish poet and dramatist. Photograph by Alice Boughton (1866-1943).

[3], writing in the New York Times: 'But most consumers don't know the difference (between areas of production of Prosecco); they just look for the name Prosecco'. The wine makers in Valdobbiadene are very upset because the EU is contemplating allowing an old Croatian grape to be called Prosek, which makes 'an obscure sweet-and still desert wine'. The real Prosecco makers are also upset at the popularity of Prosecco. According to $\mathrm{Mr}$ Bortolomio, grandmaster of the Confraternity of Valdobbiadene, the majority of bottles of Prosecco on the market are mechanically harvested and made from viticulturally uninteresting areas in the Veneto.

In my experience many Italians use the term Prosecco or spumante for sparkling wine irrespective of the grape or method of production. As pointed out [4] many different grapes can be used and some makers use the so-called 'methode champenoise' which significantly increases the price of the wine and the quality of the product. 


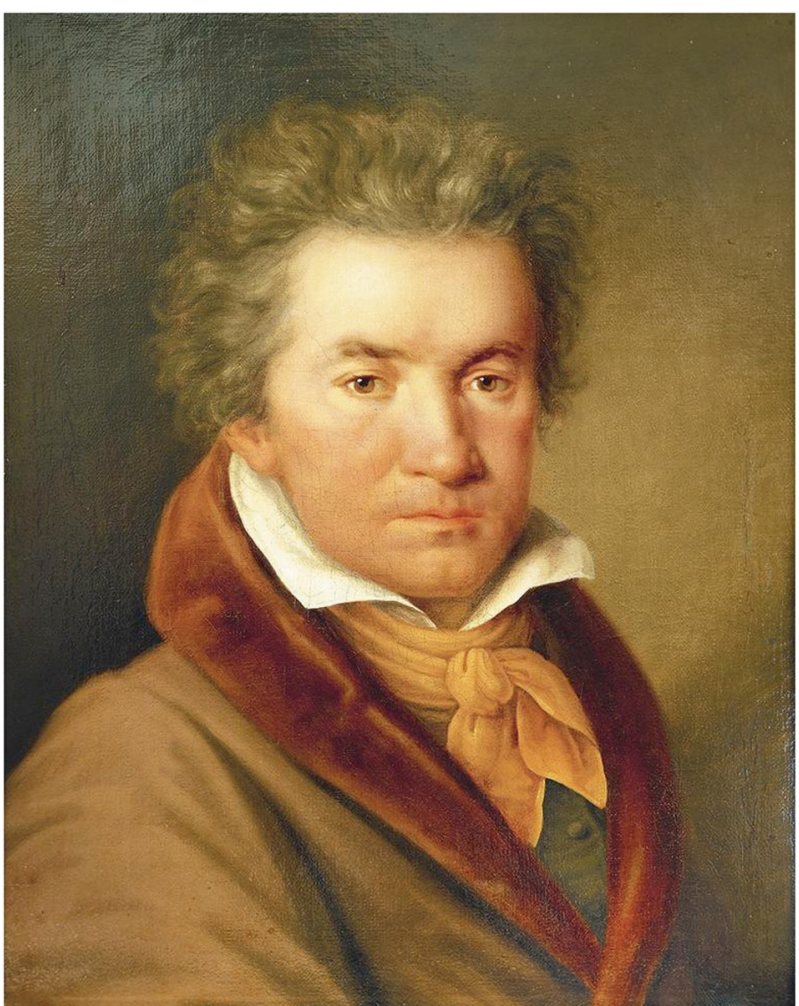

Fig. 2 Beethoven. Ludwig van Beethoven. Joseph Willibord Mähler (1778-1860). Vienna Museum, Austria. Public domain.

On a recent visit to southern Italy, primarily to see the caves in Matera, Basilicata and the trulli (houses with conical roofs) in Alberobello in Puglia, we were pleasantly surprised to find excellent sparkling wines. These wines are made from Bombino Bianco and Pinot Nero or Maresco grapes. The one we brought back was d'Arapri, Fig. 3 made from Bombino Bianco and Pinot Nero. Prices vary from about $€ 17$ and upwards and they make a beautiful aperitif. I don't think these wines are widely available outside Italy but of course they can be ordered on line. The climate in Puglia is described as Mediterranean but we were unlucky to experience heavy rain, gale-force winds and temperatures below $10^{\circ} \mathrm{C}$ forcing our retreat to sunny Tuscany.

There are many myths surrounding wine drinking from types of closure to food pairings. The myth that seems most prevalent is that sulphites give you a headache. All wine contains sulphites and as Jancis Robinson said most people who react adversely to sulphites have severe asthma. According to Robinson [5], most of the symptoms of headache, nausea and flushes, after wine drinking, are the result of biogenic amines. She also points out that the recent trend towards making wine with very little sulphite (SO2) creates a perfect environment for biogenic amine producing bacteria to flourish. White wines tend to have higher levels of sulphites than red wines. So, as Robinson says: 'Perhaps sulphur is not so sulphurous after all'.

Another intensely irritating habit by wine waiters is when they open a bottle of red wine and ask if you would like to wait a few minutes so that the wine 'can breath'. Such nonsense. The term breathing, refers to contact between the wine and oxygen. How this could happen in a few minutes when the interphase between the wine and oxygen is a few mls, beggars belief. To make red wine breath I usually pass the bottle's contents through a wine

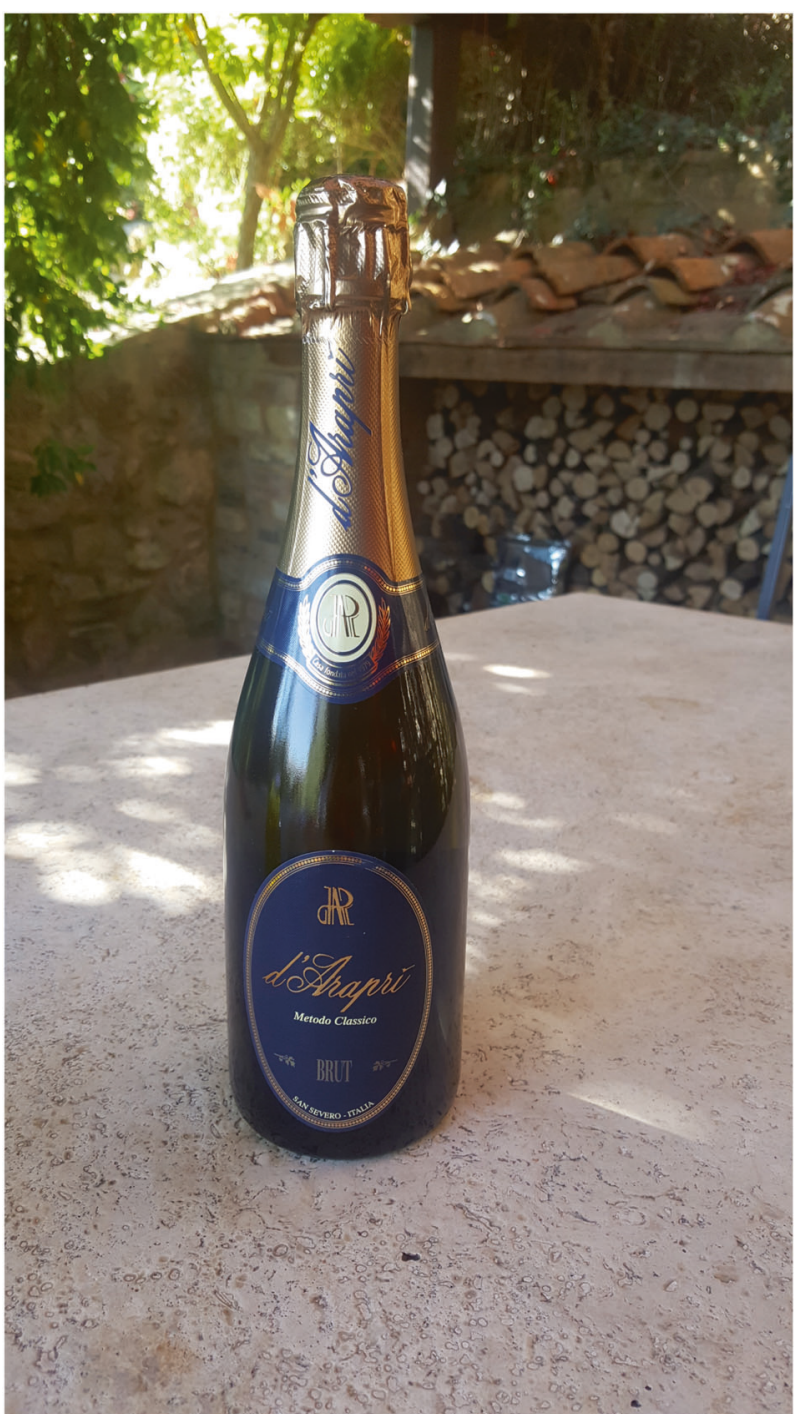

Fig. 3 Sparkling wine. A bottle of sparkling wine from $\mathrm{d}^{\prime}$ Arapri. Bombino Bianco and Pinot Nero, methode champenoise. Photograph Brenda Moore-McCann.

aerator a few hours before consumption. This allows the wine to make contact with oxygen more effectively, and breathe.

However, don't get stressed and enjoy the wine.

Shaun R. McCann (iD ${ }^{1 凶}$

${ }^{1}$ Emeritus, Department of Haematology, Trinity College, Dublin, Ireland. ${ }^{凶}$ email: shaunrmccann@gmail.com

\section{REFERENCES}

1. Gale RP and Lazarus H. The impact of cult behaviour on cell transplant practices: believers and non-believers. Bone Marrow Transpl. April 2021. https://doi.org/ 10.1038/s41409-021-0147-w.

2. McCann SR. Symptoms and signs. Bone Marrow Transpl. https://doi.org/10.1038/ s41409-018-0425-9.

3. Horowitz J. Battle of the bubbles. New York Times International Edition. October. The New York Times Company, NY 10018, USA; 2021

4. McCann SR. Fashion in haematology and wine. Bone Marrow Transplantation, 2021. https://doi.org/10.1038/s41409-021-01480-x

5. Robinson J. The message on the bottle. The weekend F/T. Financial Times: 1, Friday street, London, UK. 18/19th September 2021. 
AUTHOR CONTRIBUTIONS

S. R. M. contributed all the ideas and wrote this paper.

COMPETING INTERESTS

The author declares no competing interests.

\section{ADDITIONAL INFORMATION}

Correspondence and requests for materials should be addressed to Shaun R. McCann.

Reprints and permission information is available at http://www.nature.com/reprints

Publisher's note Springer Nature remains neutral with regard to jurisdictional claims in published maps and institutional affiliations. 